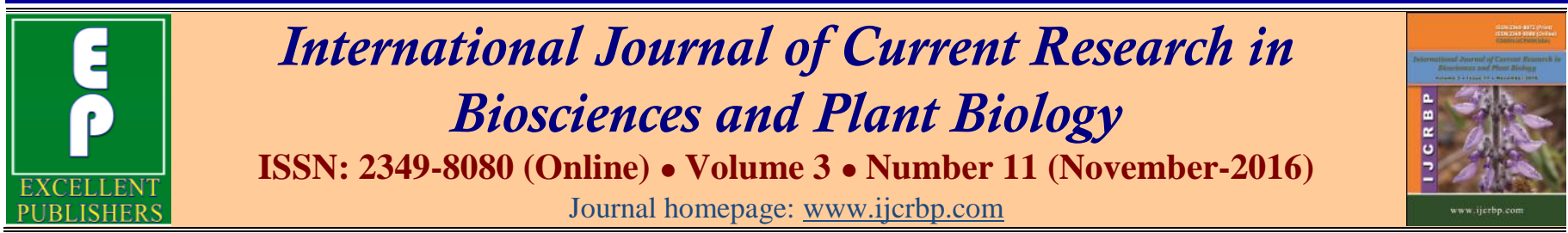

\title{
Effect of Replacing Fishmeal with Spirulina on Psychrophilic Count, Coliform and Escherichia coli in Common Carp Intestine, Muscle and Rearing Water
}

\author{
Hazhaw O. Murad'1, Hawkar J. Hamad², Ameen Al-Koye3 ${ }^{3}$ and Nasreen M. Abdulrahman ${ }^{*}$
}

${ }^{1}$ College of Veterinary Medicine, University of Sulaimani, Sulaymaniyah, Iraq

${ }^{2}$ College of Science, University of Raparin, Zharawa, Iraq

3Faculty of Agricultural Sciences, University of Sulaimani, Sulaymaniyah, Iraq

*Corresponding author.

\section{A b stract}

The use of the microalgae Spirulina in aquaculture has several potential advantages over the production of fish. This study was designed to investigate the effect of different replacement levels of fishmeal with Spirulina on some microbiology counts of common carp Cyprinus carpio L., the trail was conducted for 105 days and for this purpose 200 fingerlings common carp had been used. Five experimental diets were used and Spirulina replaced fishmeal protein from the standard diet at0\% (T1), 5\% (T2), 10\% (T3), 15\% (T4) and 20\% (T5) levels. Psychrophilic count, coliform and Escherichia coli in common carp muscle, intestine and water rearing had been examined in which no psychrophilic bacteria in carp muscles were found as compared to control that were contain $16 \times 10^{4}$, and the count of coliform bacteria decreased as the ratio of Spirulina increased in the diets, the highest was in control $1.2 \times 10^{2}$ while the lowest was in T3 with $2 \times 10$. Different count of psychrophilic bacteria were in common carp intestine; the higher was in the control group with $600 \times 10^{4}$, while the lowest count obtained in the T5 with $0 \times 10^{4}$, the same trend had been shown in the coliform counts in fish intestine in which the highest was in $\mathrm{T} 3$ with $35 \times 10^{2}$ but the lowest was in T5 with $2 \times 10$. The control showed lowest results in psychrophilic count in rearing water with $2 \times 10$ and the highest were in other treatments, regarding coliform counts the lowest value had been shown in T2 and T3 $\left(1.5 \times 10^{2}\right.$ and $\left.1.5 \times 10^{2}\right)$ respectively and the highest was in $\mathrm{T} 4\left(4 \times 10^{2}\right)$.
\end{abstract}

\section{Article Info}

Accepted: 21 October 2016

Available Online: 06 November 2016

\section{Keywords}

Coliform

Escherichia coli

Fishmeal

Psychrophilic count

Spirulina

\section{Introduction}

Increased demands for seafood products and deficiency in natural sources have promoted the aquaculture industry to supply markets with seafood products. A sustainable industry requires well-studied aquatic species from biological, physiological, nutritional and ecological aspects. Rapid growth and disease resistance are two important characteristics of the cultured animal. Therefore, antibiotics have been applied to enhance immune response and feed utilization for many years (FAO, 2010). However, due to concerns caused by the development of antibiotic resistance micro-organisms and possible harmful effects to the environment and human health, the use of antibiotics has been banned or restricted in many countries (Kesarcodi-Watson et al., 2008). 
Aquaculture is the farming of aquatic organisms in inland and coastal areas, involving intervention in the rearing process to enhance production and the individual or corporate ownership of the stock being cultivated (FAO, 2012). Diet supplementation is an important aspect in aquaculture management especially in intensive or in semi-intensive fish culture, and is promising for increasing fish production (Abdelghany and Ahmad, 2002; Abdel-Tawwab et al., 2007). However, protein is essential for normal tissue function, for the maintenance and renewal of fish body protein and for growth. Due to the cost of the protein, the feed will be more cost effective if all the protein is used for tissue repair and growth and little catabolized for energy (Gauquelina et al., 2007). Apart from developing low-cost diets, different feeding management strategies such as ondemand feeding regimes (Andrew et al., 2002). One problem facing fish culturists is the need to obtain a balance between rapid fish growth and optimum use of the supplied feed. When fish are fed with a suitable feeding frequency, growth and feed conversion ration are expected to improve because regulating their feed intake in relation to their energy demand (Kim et al., 2007).

Spirulina is a Cyanobacterium that has been commercially cultivated for more than 10 years due to its high nutritional content; e.g. protein, amino acid, vitamin, minerals, essential fatty acid and $\beta$ - carotene (Vonshak, 1997). Spirulina can be considered a nutritional supplement that has various health benefits for humans, and a feed supplement for animals having economic benefits, as an example, it can be a suitable food supplement when fed to trout, sea bass, fancy carp, red tilapia, shrimp and mollusk. It has been found that the alga can be used as an alternative source of protein and can also be used to improve the color, flavor and quality of meat (Al-Badri, 2010).

Researchers have reported the therapeutic effects of Spirulina as a growth promoter, probiotic, and booster of the immune system in animals including fishes (James et al., 2006). Spirulina is used to promote the growth of livestock, poultry, prawn, carp, canaries and exotic birds (Nandeesha et al., 2001). Preclinical testing suggests Spirulina has hypocholesterolemic, immunological, antiviral, and anti-mutagenic properties (Chamorro et al., 1996).

The number and types of bacteria lived on the skin of a live animal depends on the quality and the water contamination level, fresh water like river flakes contain several types of microorganism that has more variety than sea and oceans waters and contain a specific rate of soluble salt which determined the type and number of living bacteria, the psychrophilic and mesophilic type of microorganisms had been isolated from fish body surface, these group found on the body surface of fresh and salt water fish, the genus Pseudomonas spp. formed $40-50 \%$ of the total contamination (Aldulaimi, 1978 ). The increase in total microorganisms count in fresh fish isdue to the contamination either after fishing or to the boats and fishing tools (Frazier and Weshthoff, 1988) ICMSF (1986) determined the limited of total bacterial count as $10^{5}-10^{7} \mathrm{cfu} / \mathrm{g}$ for fre sh fish. While the average of total bacterial count on skin, gills and intestine of different types of microorganism were $10^{2}-10^{7}, 10^{3}-10^{5}$ and $10^{4}-10^{8} \mathrm{cfu} / \mathrm{cm} \mathrm{g}^{-1}$ respectively (Liston et al., 1976; Huang and Leung, 1993).

So, the aim of this study was to examine the effects of replacing fishmeal with Spirulina on some microbiological counts such as psychrophilic bacterial count, Enterobacteriaceae count and Escherichia coli in order to determine the ability of Spirulina to use as antimicrobial agents for the therapy of microbial infectious diseases and in turn enhance the health of fish, increasing the ability to fight off infections through the reduction of stress levels.

\section{Materials and methods}

Experimental animal: The experiment was conducted for 105 days and for this purpose 200fingerlings common carp Cyprinus carpio L. were brought from a local aquarium fish supplier located in Kut City, middle of Iraq. The size of fish was varying and the weights ranged between 25 and $45 \mathrm{~g}$.

The fish were sorted depending on size then weighed and put in experimental plastic aquariums. Mean initial weight was $35.7 \mathrm{~g}$. The fish were acclimated to laboratory conditions and fed with control pellets (32\% protein) prior to the feeding trials for 21 days. Twenty plastic aquariums $(100 \mathrm{~L})$ were used in this trial. Each tank was provided with a proper continuous aeration. Each aquarium was stocked with seven fish and fed two times a day. The numbers of treatments in the trial were five with four replicates for each.

In T1 fish were fed a diet replacing fishmeal with $0 \%$ Spirulina, while in T2, fish were fed a diet replacing fishmeal with 5\% Spirulina, T3 represents the third treatment, in which fish were fed on a diet replacing fishmeal with $10 \%$ Spirulina, While, in T4 fish were fed 
a diet replacing fishmeal with $15 \%$ Spirulina, and final treatment T5 replacing fishmeal with $20 \%$ Spirulina, as its shown in Table 1. The aquaria (replicates) were randomly allocated to minimize differences among treatments. The continuous water flow discharged nonconsumed feed and feces particles from the aquaria. Also, a daily cleaning by siphon method was applied to remove remained particles from the system. Table 1 represents the structure of experimental diet. In T1 fish were fed a diet replacing fishmeal with $0 \%$ Spirulina, while in T2, fish were fed a diet replacing fishmeal with 5\% Spirulina, T3 represents the third treatment, in which fish were fed on a diet replacing fishmeal with $10 \%$ Spirulina, While, in T4 fish were fed a diet replacing fishmeal with $15 \%$ Spirulina, and final treatment T5 replacing fishmeal with $20 \%$ Spirulina.

Table 1. The structure of experimental diet.

\begin{tabular}{llllll}
\hline Composition of diet & \multicolumn{3}{l}{ Basis on $\mathbf{1 0 0} \mathbf{~ k g}$} & & \\
\hline Spirulina & $0 \%$ & $5 \%$ & $10 \%$ & $15 \%$ & $20 \%$ \\
Fishmeal & 24.2 & 21.7 & 19.2 & 16.8 & 14.2 \\
Wheat bran & 35 & 35 & 35 & 35 & 35 \\
Soybean & 20 & 20 & 20 & 20 & 20 \\
Broken rice & 20.3 & 17.8 & 15.3 & 12.7 & 10.3 \\
Vitamin & 0.5 & 0.5 & 0.5 & 0.5 & 0.5 \\
Chemical composition & & & & & \\
Crude protein \% & 32 & 32 & 32 & 32 & 32 \\
Crude fat and oils \% & 6.7 & 6.4 & 6.0 & 5.7 & 5.4 \\
Fiber \% & 7.6 & 7.6 & 7.5 & 7.5 & 7.5 \\
\hline
\end{tabular}

Used Spirulina: $500 \mathrm{~g}$ of premium sinking Spirulina wafers, these top quality-sinking wafers are rich in Spirulina suitable for all herbivorous fish such as pleco's and catfish as well as shrimps and snails. Their chemical composition as labeled in the Table 2 below.

Table 2. Chemical composition of used Spirulina as labeled.

\begin{tabular}{ll}
\hline Composition & Ratio \% \\
\hline Crude Protein & $34 \%$ \\
Crude fat and oils & $6 \%$ \\
Fibre & $5 \%$ \\
Ash & $10 \%$ \\
Vitamin A(Per KG) & $24000 \mathrm{IU}$ \\
Vitamin D & $2600 \mathrm{IU}$ \\
Vitamin E & $280 \mathrm{IU}$ \\
Vitamin C & $550 \mathrm{mg} / \mathrm{kg}$ \\
\hline
\end{tabular}

\section{Psychrophilic bacterial count}

Fish tissue (1g) was aseptically excised mixed with $9 \mathrm{ml}$ ofbuffered peptone water $(0.1 \%$ BPW $\quad \mathrm{w} / \mathrm{v})$ and homogenized by using sterile mortar and transferred to sterile test tube, this was the first $10^{-1}$ dilution, series of dilutions were prepared in $9 \mathrm{ml}$ of Butterfield's phosphate diluent until $10^{-7}$. One $\mathrm{ml}$ was removed from each dilution and put in 2 Petri-dishes, Plate Count Agar (Biolife, Italy) was cooled in a water bath to $45 \pm 1^{\circ} \mathrm{C}$ and poured into the Petri-dishes, mixed gently by swirling or tilting each plate. The plates were incubated at a $5 \pm 1{ }^{\circ} \mathrm{C}$ for 10 days as described by $\operatorname{ICMSF}(1978)$.

\section{Enterobacteriaceae count}

The procedure of ICMSF (1986) had been followed. From the same previous dilutions, one $\mathrm{ml}$ from the aliquote was transferred to duplicate Petri dishes and 15 $\mathrm{ml}$ of cooled violet red bile Agar (VRBA) (Oxoid) was added and immediately mixed with the sample. After the agar had set, a second layer $(10 \mathrm{ml})$ of VRBG agar was added and allowed to set. The plates were incubated at $35^{\circ} \mathrm{C}$ for $24 \mathrm{hrs}$ after which the numbers of pink colonies were recorded.

\section{E. coli}

Eosin-Methylene Blue agar (EMB), were used, which was selective and differential for fecal Coliforms ( $E$. coli), after incubation at $37^{\circ} \mathrm{C}$ for $24 \mathrm{hrs}$, the plates were examined for typical $E$. coli colonies, which are metallic green sheen. A number (2-3) of isolated colonies were picked out and purified on EMB, then subcultured to Nutrient agar slants and incubated at $35^{\circ} \mathrm{C}$ for $18-24 \mathrm{hrs}$ to be tested completely through the complete test (APHA, 1992).

\section{Results and discussion}

In Table 3, there is no psychrophilic bacteria in carp muscles as compared to control which contain $16 \times 10^{4}$, the count of coliform bacteria decreased as the ratio of 
Spirulina increased in the diets in which the highest was in control $1.2 \times 10^{2}$ while the lowest was in T3 with $2 \times 10$.

Data in Table 4 show different count in psychrophilic count in common carp intestine; the higher was in the control group with $600 \times 10^{4}$, the lowest count obtained in the T5 with $0 \times 10^{4}$, the same trend showed in the coliform counts in fish intestine in which the highest was in T3 with $35 \times 10^{2}$ but the lowest in T5 with $2 \times 10$.

Table 3. Effect of replacing fishmeal with Spirulina on psychrophilic count, coliform and E. coli in common carp muscle.

\begin{tabular}{llll}
\hline Treatment & Psychrophilic count & Coliform & E. coli \\
\hline T1 & $16 \times 10^{4}$ & $1.2 \times 10^{2}$ & $-\mathrm{ve}$ \\
T2 & $0 \times 10^{4}$ & $6 \times 10$ & $+\mathrm{ve}$ \\
T3 & $0 \times 10^{4}$ & $2 \times 10$ & $-\mathrm{ve}$ \\
T4 & $0 \times 10^{4}$ & $8 \times 10$ & $-\mathrm{ve}$ \\
T5 & $0 \times 10^{4}$ & $3 \times 10$ & $-\mathrm{ve}$ \\
\hline
\end{tabular}

Table 4. Effect of replacing fishmeal with Spirulina on psychrophilic count, coliform and E. coli in common carp intestine.

\begin{tabular}{llll}
\hline Treatment & Psychrophilic count & coliform & E. coli \\
\hline T1 & $600 \times 10^{4}$ & $19 \times 10^{2}$ & $-\mathrm{ve}$ \\
T2 & $42 \times 10^{4}$ & $22 \times 10^{2}$ & $-\mathrm{ve}$ \\
T3 & $32 \times 10^{4}$ & $35 \times 10^{2}$ & $-\mathrm{ve}$ \\
T4 & $120 \times 10^{4}$ & $7 \times 10^{2}$ & $+\mathrm{ve}$ \\
T5 & $0 \times 10^{4}$ & $2 \times 10$ & $-\mathrm{ve}$ \\
\hline
\end{tabular}

In Table 5, a different results obtained in which the control group showed lowest results in psychrophilic count in rearing water with $2 \times 10$ and the highest in other treatments, in regarding coliform counts lowest value had been shown in T2 and T3 $\left(1.5 \times 10^{2}\right.$ and $1.5 \times 10^{2}$ respectively) and the highest in $\mathrm{T} 4\left(4 \times 10^{2}\right)$.

Table 5. Effect of replacing fishmeal with Spirulina on psychrophilic count, coliform and E. coli in common carp water rearing.

\begin{tabular}{llll}
\hline Treatment & Psychrophilic count & Coliform & E. coli \\
\hline T1 & $2 \times 10$ & $2.5 \times 10$ & + ve \\
T2 & $62 \times 10$ & $1.5 \times 10^{2}$ & - ve \\
T3 & $28 \times 10$ & $1.5 \times 10^{2}$ & + ve \\
T4 & $83 \times 10$ & $4 \times 10^{2}$ & $-v e$ \\
T5 & $12 \times 10$ & $2 \times 10$ & $-v e$ \\
\hline
\end{tabular}

In the study of Abdel-Tawwab et al. (2008), the results of bacteria challenge, bactericidal activity, and NBT suggest the increase in phagocytosis in blood, which have an important role for prevention of infectious disease. Phagocytosis by these cells is a process of internalization, killing and digestion of invading microorganisms, in phagocytosis; phagocytes produce oxygen free radicals during the respiratory burst, which is toxic to bacteria as regards to our results observed in Table 5 , an increase in Spirulina level leads to lowest the coliform counts but it causing to increase the coliform in $\mathrm{T} 4$.

Al-Koye (2013) found the total bacterial account in the rearing water and intestine 231.667 and 683.333 observed in T3 respectively had significant $(p<0.05)$ different among other dietary treatments and this was in the same trend in our study in which the lowest count was in T4 that agree with our results. Watanuki et al. (2006) estimated the fluctuation in the number of bacterial cells in Spirulina-treated fish organs after an artificial challenge with Aeromonas hydrophila. They found that the bacteria numbers were lower in the liver and kidney of carp treated with Spirulina than the control treatment suggesting the increased resistance $A$. hydrophila infection.

Provide specifications for Spirulina, which include specifications for protein, lead, minerals, moisture, betacarotene, total carotenoids, c-phycocyanin, arsenic, cadmium, mercury, pesticides, rodent hairs, and insect fragments, there also established the absence of $E$. coli, Salmonella and Staphylococcus aureus, total aerobic bacteria of less than 200,000 colony forming units per gram $(\mathrm{cfu} / \mathrm{g})$, and total coliforms of less than $10 \mathrm{cfu} / \mathrm{g}$. The composition of Spirulina, as an example of Spirulina powder used is Pacifica ${ }^{\mathrm{TM}}$ which is a free-flowing green to bluish-green powder, it has a mild seaweed odor and is not soluble; it forms a suspension. The particle size is $<125$ microns and bulk density is $>0.48(\mathrm{~g} / \mathrm{ml})$. Total aerobic bacteria: <105 cfu/g; Total coliforms: $<10 \mathrm{cfu} / \mathrm{g}$ 
E. coli; Negative pesticides: negative arsenic: $<0.5 \mathrm{ppm}$. Cadmium: <0.2 ppm; Lead: <0.2ppm; Mercury: <0.025 ppm; Salmonella: negative (Osman et al., 2011). Borowitzka (1997) have attributed the Cyanophyta antimicrobial activity to different compounds. As only crude extracts of Spirulina examined, thus, the result of the present study supports the folkloric usage of the studied Cyanobacteria and suggests that the Spirulina extract possesses certain constituents with antibacterial properties that can be used as antimicrobial agents for the therapyof microbial infectious diseases. The extracts showed maximum activity against pathogenic microbes subjected to isolation of the therapeutic antimicrobials and hence the need to carry out further pharmacological evaluation (Pradhan et al., 2012).

\section{Conflict of interest statement}

Authors declare that they have no conflict of interest.

\section{References}

Abdelghany, A. E., Ahmad, M. H., 2002. Effects of feeding rates on growth and production of Nile tilapia, common carp and silver carp polycultured in fertilized ponds. Aquacult. Res. 33, 415-423.

Abdel-Tawwab, M., Abdelghany, A. E., Ahmad, M. H., 2007. Effect of diet supplementation on water quality, phytoplankton community structure, and the growth of Nile tilapia, Oreochromis niloticus (L.), common carp, Cyprinus carpio L., and silver carp, Hypophthalmichthys molitrix V. polycultured in fertilized earthen ponds. J. Appl. Aquacult. 19(1), 1- 24.

Abdel-Tawwab, M., Abdel-Rahman, A. M., Ismael, N. E. M., 2008. Evaluationof commercial live bakers' yeast, Saccharomyces cerevisiae as a growth and immunity promoter for fry Nile tilapia, Oreochromis niloticus (L.) challenged in situ with Aeromonas hydrophila. Aquaculture. 280, 185-189.

Al-Badri, S. H. A., 2010. Effect of environmental factors and some pollutants on the chemical content and nutritional value of blue-green alga Spirulina platensis (Nordst) Geilter. M.Sc. thesis, College of Education, University of Thi-Qar. 187p.

Aldulaimi, Kh. S., 1978. Food Microbiology. College of Agriculture, Baghdad University, Iraq (In Arabic).

Al-Koye, 2013. Effect of Using Spirulina spp. Instead of Fishmeal on Growth, Blood Picture and Microbial Load of Common Carp, Cyprinus carpio. M.Sc. Thesis, College of Agriculture, University of Salahaddin, Iraq. 103p.

Andrew, J. E., Noble, C., Kadri, S., Jewell, H., Huntingford, F. A., 2002. The effect of demand feeding on swimming speed and feeding responses in Atlantic salmon Salmo salar L., gilthead sea bream Sparus aurata L. and
European sea bass Dicentrarchus labrax L. in sea cages. Aquacult. Res. 33, 501-507.

APHA (American Public Health Association), 1992. Compendium of Methods for the Microbiological Examination of Food. $3^{\text {rd }}$ Ed., Washington, DC, New York.

Borowitzka, M.A., 1997. Microalgae for aquaculture: Opportunities and constraints. J. Appl. Phycol. 9(5), 393401.

Chamorro, G., Salazar, M., Favila, L., Bourges, H., 1996. Pharmacology and toxicology of Spirulina alga. Rev. Invest. Clin. 48, 389-399.

FAO, 2010. The State of World Fisheries and Aquaculture, (SOFIA), FAO Fisheries and Aquaculture. Department Food and Agriculture Organization of the United Nations, Rome. 93p.

FAO, 2012. Report of the Thirtieth Session of the Committee on Fisheries. FAO Fisheries and Aquaculture Report. No. 1012, Rome. 75p.

Frazier, W. C., Weshthoff, D. C., 1988. Food Microbiology. $4^{\text {th }}$ Edn. Mc Graw-Hill Book Company, New York.

Gauquelina, F., Cuzona, G., Gaxiolab, G., Rosasb, C., Arenab, L., Bureauc, D.P., Cocharda, J.C., 2007. Effect of dietary protein level on growth and energy utilization by Litopenaeus stylirostris under laboratory conditions. Aquaculture. 271(1-4), 439-448.

Huang, Y. W., Leung, C. K., 1993. Microbiological assessment of channel catfish grown in cage and pond culture. Food Microbiol. 10, 187-195.

ICMSF, 1978. Part I. Important consideration for the analyst. In: Microorganisms in Foods: Their Significance and Methods of Enumeration (Eds.: Elliot, R. P., Clark, D. S., Lewis, K. H., Lundbeck, H., Olson, Jr. J. C., Simonsen, B.). $2^{\text {nd }}$ Edn. University of Toronto Press, Toronto. pp.91102.

ICMSF, 1986. International Commission on Microbiological Specifications for Food of the International Union of Microbiological Societies. Microorganisms in Food 2: Sampling for Microbiological Analysis Principles and Specific Application. $2^{\text {nd }}$ Edn., University of Toronto Press, Toronto, Canada.

James, R., Sampath, K. W., Thangarathinam, R., Vasudhevan, I., 2006. Effect of dietary Spirulina level on growth, fertility, coloration and leucocytecount in red swordtail, Xiphophorus helleri. Isr. J. Aquacult. Bamidgeh. 58, 97104.

Kesarcodi-Watson, A., Kaspar, H., Josie, L.M., Gibson, L., 2008. Feed additives in aquaculture: The need, principles and mechanisms of action and screening processes. Aquaculture. 274, 1-8.

Kim, K.D., Kang, Y. J., Kim, K. W., Kim, K.M., 2007. Effects of feeding rate on growth and body composition of juvenile flounder, Paralichthys olivaceus. J. World Aquacult. Soc. 38(1), 169-173.

Liston, J., Stansby, M. E., Olcott, H. S., 1976. Bacteriological and chemical basis for deteriorative changes. In: Industrial 
Fishery Technology (Ed.: Stansby, M. E.). Robert. E. Kriegor, New York. pp.345-358.

Nandeesha, M., Gangadhara, B., Maniseery, J., Venkataraman, L., 2001. Growth performance of two Indian major carps, (Catla catla and Labeo rohita) fed diets containing different levels of Spirulina platensis. Bioresour. Technol. 80(2), 117-120.

Osman, G. A., Ali, M. S., Kamel, M. M., Gad, A. A., 2011. The role of Cladophora spp. and Spirulina platensis in the removal of microbial Nile water. J. Amer. Sci. 7(1), 1-7.

Pradhan, J., Das, B. K., Sahu, S., Marhual, N. P., Swain, A. K., Mishra, B. K., Eknath, A. E., 2012. Traditional antibacterial activity of fresh water microalga Spirulina platensis to aquatic pathogens. Aquacult. Res. 43, 12871295.

Vonshak, A., 1997. Appendices: Spirulina platensis (Arthrospira): Physiology Cell-biology and Biotechnology. Taylor and Francis Ltd., London. 214p. Watanuki, H., Ota, K., Malin, A. C., Tassakka, A. R., Kato, T., Sakai, M., 2006. Immunostimulant effects of dietary Spirulina platensis on carp, Cyprinus carpio. Aquaculture. 258, 157-163.

\section{How to cite this article:}

Murad, H. O., Hamad, H. O., Al-Koye, A., Abdulrahman, N. M., 2016. Effect of replacing fishmeal with Spirulina on psychrophilic count, coliform and Escherichia coli in common carp intestine, muscle and rearing water. Int. J. Curr. Res. Biosci. Plant Biol. 3(11), 43-48. doi: http://dx.doi.org/10.20546/ijcrbp.2016.311.007 